safeguards or international inspection rights (it is in fact the only reactor apart from the Canadian-Indian plant which is unsafeguarded). According to representative Melvin Price, Chairman of the Congressional Joint Committee on Atomic Energy (JCAE), it is capable of producing $8 \mathrm{~kg}$ of plutonium a year, which is almost enough for a crude bomb. The country is not known to have constructed a plant for separating out the plutonium from the spent fuel rods, but according to one US official, it could do so relatively easily. Thus, whatever safeguards are applied to the proposed power reactor, Israel would still be capable of joining the nuclear club if she chooses to do so. It should also be noted that neither Israel nor Egypt has ratified the Nonproliferation Treaty, although Egypt has signed it.

Be that as it may, the nuclear deals are likely to be developed as follows. Israeli and Egyptian officials have been in Washington this week to negotiate contracts for the supply of fuel to the reactors. These negotiations, ironically, have to be completed before agreement is reached on the reactor sales because the Atomic Energy Commission has set a June 30 deadline for new contracts involving the delivery of enriched uranium to foreign countries in the early 1980s. Then, a few weeks later, negotiations will begin on the sale of the reactors themselves. If agreement is eventually reached the JCAE will be informed and Congress will have 30 days in which to react. The agreement could be prevented from going into effect only if Congress passes a bill disapproving the terms under which the sale will take place. But the Bill would be subject to a possible presidential veto.

Representative Price has promised that the JCAE will give the matter a full and open review, and he has said that he "will keep (Congress) appropriately informed." of developments, during the negotiations.

But several members of Congress are dissatisfied with that arrrangement, and are attempting to give Congress veto power over any international agreement involving the export of nuclear technology. Representative Lester Wolff has already introduced a Bill into the House which will prevent the Middle East agreements from going into effect until Congress gives its express approval of the deal, and Senator William Proxmire has announced his intention to propose an amendment to the Export Administration Act when it comes before the Senate in the next few weeks, which will require that "no nuclear technology, nuclear materials, or associated equipment could be sent to any country until both houses of Congress give approval in a vote". According to a staff member of the JCAE, however, such a requirement would place a huge burden on Congress because in the past six months alone the United States has entered into some 50 separate agreements involving such transactions.

In contrast to the nuclear agreements, the scientific exchange proposals announced by President Nixon have scarcely raised a flicker of interest in the United States. As far as Egypt is concerned, Nixon and President Sadat announced in a joint communique that their two governments will establish a series of working groups to meet in the near future to prepare concrete projects and proposals for bilateral research in the fields of agriculture, "technology, research and development in scientific fields including space, with special emphasis on the exchange of scientists," and medical research.

Such activities will supplement the present limited scientific cooperation between the two countries, which is funded to the tune of about $\$ 1.5$ million a year through excess US currency in Egypt (so-called PL480 funds). At this stage, the proposal is simply an agreement to cooperate and no concrete projects have been decided. Similar arrangements are proposed with Jordan and Saudi Arabia.

As for Israel, the agreement is less specific, referring only to the need for "further encouragement of the fruitful links already existing between the two countries in the scientific and technical field, including space research.
A "NEW ERA" for coal is forecast by the Secretary of State for Energy, Mr Eric Varley, in his introduction to the interim report of the examination into the coal industry (published by the Department of Energy) carried out jointly by the government, the National Coal Board and the mining unions.

After the depression in the British coal industry in the 1960 s the report paints a much more hopeful picture of the future for the industry into the 1980 s and beyond. Future demand for coal will be at least equal to if not greater than the present 130 million tons a year, predicts the report. But to satisfy this demand the industry will have to "run very fast to keep still" to the tune of $£ 600$ million in capital investment by 1985 . New capacity of 42 million tons a year will be needed by 1985 to replace the coal lost by exhaustion of existing mines.

Twenty million tons of this is expected to come from new fields. The big Selby coalfield in Yorkshire will contribute up to 10 million tons a year by 1985 (it is hoped) and Mr Varley, in reply to a question in Parliament, said that the possibility of developing the rich seam of coal under Oxfordshire is being actively explored.

\title{
New King Coal
}

\section{by Eleanor Lawrence}

Nine million tons a year would come from the life extension of pits which would otherwise be quickly exhausted, and the remaining 13 million tons from new schemes at existing pits. With opencast mining a total production of 150 million tons a year is to be the ultimate target.

The upswing in the fortunes of coal follows the dramatic rise in the oil prices during the past year, which has again made coal a fuel competitive with oil. Economic conditions for a thriving industry are right for the first time in twenty years, says Mr Varley. Now the coal industry can be both competitive and commercially self-sufficient.

The electricity boards are the coal industry's main customers, taking $58 \%$ of National Coal Board (NCB) production in 1973, and the future of coal depends to a large extent on their long term policies. The Central Electricity Generating Board (CEGB) has told the committee that, providing coal remains competitive with oil, the boards will continue to take as much NCB coal as they can get. The CEGB reckons that in 1985 it will be able to burn about 90 million tons (compared with the 76 million tons it took in 1973). But the industry fears that this potential demand will not be realised unless new coalfired generating capacity is built.

In the event the NCB has shown itself amply justified in its whole-hearted endorsement of the future of coal even when things looked blackest. The industry contracted from an output of 210 million tons and a workforce of 770,000 men in 1959 to 130 million tons and 270,000 men in 1973. The government is obviously determined not to return to the situation of the $1960 \mathrm{~s}$, when the increasing dependence on cheap oil led to the running down of the industry, and promise in the report that the industry shall not be at the mercy of short term fluctuations in the price of competing fuels.

Mr Varley said in Parliament last week that it would need "superhuman effort" from the industry to meet the ultimate target of 150 million tons a year. Production is down this year and two major strikes in the past three years have cast doubts on the essential condition of security of supply. 